\title{
ПРАВОВЕ ЗАБЕЗПЕЧЕННЯ ЗАСТОСУВАННЯ СЛУЖБОЮ БЕЗПЕКИ УКРАЇНИ МЕТОДІВ КОНТРРОЗВІДУВАЛЬНОЇ ДІЯЛЬНОСТІ
}

Пелюх О. С.

Європейський вибір України, демократизація українського суспільства та розбудова сучасної системи забезпечення державної безпеки зумовлюють необхідність створення належної нормативно-правової основи організації та діяльності органів та підрозділів контррозвідки Служби безпеки України, яка має бути максимально наближеною до європейських стандартів.

у статті проаналізовано нормативно-правові акти, які регулюють правові відносини у сфері застосування Службою безпеки України методів контррозвідувальної діяльності, та запропоновано низку рішень з удосконалення їх правового забезпечення. Розглянуто новели, що пропонуються до закріплення в законодавстві України у сфері забезпечення державної безпеки. Метою статті $\epsilon$ дослідження нормативно-правового забезпечення застосування Службою безпеки України методів контррозвідувальної діяльності, виявлення проблем їх правового регулювання та надання пропозицій щодо їх вирішення.

Зроблено висновок, що методи контррозвідувальної діяльності мають власну правову природу. Зокрема, прямі посилання в законодавстві на методи контррозвідувальної діяльності не розкривають їхніх сутнісних та змістовних характеристик, не впливають на формування їх системи, хоча і формулюють окремі з них. При цьому інші норми контррозвідувального законодавства хоча прямо і не вказують на них, але здійснюють найбільший вплив на їхню правову природу, або накладають певні обмеження в їх застосуванні за певних обставин. До зазначених норм можна зарахувати статmі, що закріплюють мету та завдання контррозвідувальної діяльності, іï принципи, підстави та форми їі проведення, функції і повноваження органів та підрозділів контррозвідки, гарантії дотримання законності під час здійснення контррозвідувальної діяльності тощо.

Законодавство України є системним утворенням. Системний аналіз юридичних норм, що становлять правову основу контррозвідувальної діяльності, надав, на наш погляд, змогу, по-перше, відтворити механізм впливу норм права на методи контррозвідувальної діяльності, по-друге, встановити внутрішні та зовнішні юридичні зв'язки між досліджуваною категорією та іншими важливими категоріями контррозвідувальної діяльності, по-третє, зрозуміти залежність між правовою дійсністю та навколишніми соціальними явищами, процесами, на які можуть впливати методи контррозвідувальної діяльності в результаті їх застосування.

Ключові слова: контррозвідувальна діяльність, метод контррозвідувальної діяльності, контррозвідувальний захід, принцип конспірації, принцип поєднання гласних і негласних форм та методів.

Peliukh 0. S. Legal support of using methods of counterintelligence activity by the Security Service of Ukraine

Ukraine's European choice, democratization of Ukrainian society and development of a modern system of Ukraine's state security necessitate the creation of an appropriate legal framework for the organization and activities of counterintelligence bodies and units of the Security Service of Ukraine, which should be as close as possible to European standards.

The article analyzes the legal acts that regulate legal relations in the field of application of counterintelligence methods by the Security Service of Ukraine and proposes a number of solutions to improve their legal support. The novelties offered for enshrinement in the legislation of Ukraine in the field of state security are considered. The purpose of the article is to study the regulatory and legal support for the use of counterintelligence methods by the Security Service of Ukraine, to identify problems of their legal regulation and to provide proposals for their solution.

As a result, it was concluded that the methods of counterintelligence activities have their own legal nature. In particular, direct references in the legislation to the methods of counterintelligence activities do not disclose their essential and substantive characteristics, do not affect the formation of their system, although they formulate some of them. At the same time, other norms of counterintelligence legislation, although they do not directly indicate them, have the greatest impact on their legal nature, or impose certain restrictions on their application in certain circumstances. These norms include articles that establish the purpose and objectives of counterintelligence activities, its principles, grounds and forms of its conduct, functions and powers of counterintelligence bodies and units, guarantees of legality during counterintelligence activities, etc.

(c) Пелюх О. С., 2020 
The legislation of Ukraine is a systemic entity. Systematic analysis of legal norms that constitute the legal basis of counterintelligence activities, provided, in our opinion, the opportunity: first, to reflect the mechanism of influence of law on the methods of counterintelligence activities; second, to establish internal and external legal links between the category under study with other important categories of counterintelligence activities; third, to understand the relationship between legal reality and the surrounding social phenomena, processes that may be affected by methods of counterintelligence as a result of their application.

Key words: counterintelligence activity, method of counterintelligence activity, counterintelligence measure, principle of conspiracy, principle of combination of explicit and implicit forms and methods.

Постановка проблеми та іï актуальність. Сучасне законодавство у сфері забезпечення державної безпеки повинно мати досить розроблений понятійно-категоріальний апарат, високий рівень системності й узгодженості елементів нормативно-правової бази, забезпечуючи відсутність у законодавчих і підзаконних актах, що їі утворюють, істотних прогалин і колізій, декларативності й суперечливості деяких юридичних приписів, дефінітивних дефектів, а також відмову від фрагментарної визначеності у праві державної безпеки та іï загроз [1, с. 160].

Європейський вибір України, демократизація українського суспільства та розбудова сучасної системи забезпечення державної безпеки України зумовлюють необхідність створення належної нормативно-правової основи організації та діяльності органів та підрозділів контррозвідки СБ України, яка має бути максимально наближеною до європейських стандартів.

Зазначений вектор розвитку нашої держави зумовлює масштабні перетворення, необхідні для становлення України як правової держави. Серед них в умовах реформи сектора безпеки і оборони взагалі і СБ України, зокрема, актуальною $\epsilon$ проблема нормативно-правового забезпечення застосування методів контррозвідувальної діяльності (далі - КРД), яка останнім часом знаходиться в центрі уваги як практиків, так і науковців не тільки відомчої науки.

Аналіз останніх досліджень i публікацій свідчить, що дослідження нормативно-правового забезпечення саме методів діяльності підрозділів контррозвідки СБ України проводиться вперше, хоча окремі проблемні аспекти правового регулювання КРД, які впливають і на їі методи, знаходились у колі наукових пошуків провід- них вітчизняних науковців, таких як О.О. Вовк, М.М. Галамба, С.Г. Гордієнко, І.П. Козаченко, С.В. Корнаков, В.В. Крутов, Б.П. Курашвілі, О.Р. Лебедєв, Ю.О. Найдьон, В.Я. Настюк, В.Г. Пилипчук, П.С. Підгайний, О.Б. Розвадовський, І.В. Слюсарчук, М.П. Стрельбицький, А.А. Фабрічніков, В.П. Фомичьов, М.О. Шилін, О.М. Юрченко, А.О. Янчук, В.П. Ярковський, О.Н. Ярмиш, В.А. Ященко та ін.

Проте системний аналіз наукових досліджень та навчально-методичної літератури, присвячених правовому забезпеченню застосування СБ України методів КРД, свідчить про фрагментарне дослідження зазначених проблем та зумовлює проведення окремого дослідження у визначеному напрямі.

Метою статті $\epsilon$ дослідження нормативно-правового забезпечення застосування Службою безпеки України методів контррозвідувальної діяльності, виявлення проблем їх правового регулювання та надання пропозицій щодо їх вирішення.

Виклад основного матеріалу. Правова основа КРД становить сукупність правил, що регулюють суспільні відносини, які передбачають нормативну модель функціонування органів та підрозділів контррозвідки з реалізації своїх прав і виконання покладених обов'язків для досягнення мети із забезпечення державної безпеки України. Законодавство визначає межі належної та можливої поведінки підрозділів контррозвідки, компетенцію та повноваження посадових осіб щодо реалізації контррозвідувальних заходів, під час яких застосовуються методи КРД, а також забезпечення гарантій законності в процесі реалізації СБ України своїх повноважень.

Водночас варто зауважити, що питання нормативно-правового забезпечення саме методів КРД досить складне та потребує системного та комплексного аналізу. Так, з огляду на незначну кількість конкретних посилань на методи КРД у національному законодавстві, підзаконних нормативно-правових актах, більшість загальних правових положень, що регулюють правові відносини у сфері КРД, опосередковано впливають на формування їхньої правової природи, системи, сутності та змісту, що формує їх фундаментальні організаційно-правові засади.

Аналізуючи нормативно-правові акти, що прямо або опосередковано впливають на методи КРД СБ України або формують їх систему, обов'язково необхідно дослідити прямі посилання законодавства на них. Однак необхідно визнати, що законо- 
давство України не розкриває їх сутність, зміст, поняття та систему, що повною мірою відповідає нашому баченню щодо законодавчого закріплення методів КРД. Нормативне закріплення може позбавити їх певних змістовних та сутнісних характеристик, а також може призвести до процесуалізації КРД, що, на нашу думку, негативно вплине на стан забезпечення державної безпеки України. Чіткого нормативно-правового закріплення потребують контррозвідувальні заходи, а методи мають залишатись у сфері теоретико-методологічного регулювання.

Так, основним нормативно-правовим актом, в якому найбільш ґрунтовно відображається сутність методів КРД, є Закон України «Про контррозвідувальну діяльність». У диспозиції статей цього Закону зазначається, що методи КРД можуть бути гласними і негласними, за наявності підстав для проведення КРД вони можуть застосовуватись для перевірки інформації про можливе проведення розвідувально-підривної, терористичної та іншої протиправної діяльності на шкоду державній безпеці України, а також про те, що гласні та негласні контррозвідувальні заходи передбачають використання гласних та негласних методів відповідно [2, ст.ст. 4, 6, 8, 9]. На нашу думку, найбільший вплив на порядок застосування системи методів КРД справляють норми, що закріплюють iï мету та завдання, принципи, підстави та форми iï проведення, функції i повноваження органів та підрозділів контррозвідки, гарантії дотримання законності під час здійснення КРД тощо.

КРД є основним видом діяльності СБ України як національної спецслужби в протидії розвідувальній діяльності спецслужб іноземних держав. Діяльність останніх на шкоду державній безпеці України здійснюється, як правило, негласно, що фактично формує систему методів протидії такій діяльності, які не можуть бути ефективними, маючи гласну форму. Тому здебільшого протидія іноземним спецслужбам реалізується шляхом застосування негласної частини методів КРД СБ України.

Звісно, запропонований законодавцем поділ методів КРД на гласні та негласні відповідно до критерію конспіративності в діяльності підрозділів контррозвідки СБ України відображає їхні сутнісні та змістовні характеристики. Однак національній спецслужбі потрібно мати змогу адекватно й ефективно реагувати на хитрощі іноземних спецслужб, які вони застосовують для збору розвідувальної інформації на території нашої держави. Для цього, на нашу думку, в законодавстві варто надати їм таку характеристику, як «спеціальні методи», яка закріплена п. 1 ч. 1 ст. 6 Закону України «Про контррозвідувальну діяльність» [2, ст. 6], тобто такі, які характерні виключно для контррозвідувальних підрозділів, що характеризують СБ України як національну спецслужбу зі спеціальними можливостями, якою вона іє в системі органів забезпечення державної безпеки України.

Інше згадування про методи КРД у зазначеному Законі закріплює конспірацію, поєднання гласних та негласних форм і методів діяльності як один з основних іï принципів, які виступають системою закріплених на законодавчому рівні правових засад їі ведення, що відображають її соціальну значущість та визначають побудову форм їі реалізації. Прикладом реалізації на практиці цих принципів може бути негласне отримання контррозвідкою інформація про причетність особи до створення причин та умов, що за певних обставин можуть негативно позначитись на стані забезпечення державної безпеки. А їі реалізація шляхом переконання особи від імені органів СБ України припинити створювати такі умови, нівелювати зазначені причини, а також наполеглива вимога контррозвідки не створювати їх надалі реалізується гласно під час офіційної розмови. Реалізація принципу поєднання гласних і негласних форм та методів також полягає в тому, що права підрозділів контррозвідки, реалізацією яких $\epsilon$ проведення контррозвідувальних заходів, чітко визначені законодавством, тобто є гласними, а інформація про форми та методи їх реалізації не підлягає розголошенню, а отже, $є$ негласною. Таким чином, поєднання гласних і негласних форм та методів діяльності контррозвідки $\epsilon$ важливою передумовою офіційного використання фактичних даних, отриманих здебільшого негласним шляхом.

Крім того, в Законі України «Про контррозвідувальну діяльність» розкриваються аксіоматичні поняття гласних та негласних контррозвідувальних заходів, під час реалізації яких можуть бути застосовані гласні та негласні методи відповідно. Зокрема, в ч. 4 та 5 ст. 8 під гласними контррозвідувальними заходами законодавець розуміє використання відкритих (офіційних) форм і методів роботи у сфері забезпечення державної безпеки. А негласні здійснюються із залученням осіб, які конфіденційно співпрацюють із контррозвідувальними органами і підрозділами, а також із використанням оперативних, оперативно-технічних та спеціальних сил і засобів. При цьому Закон України «Про контррозвідувальну діяльність» передбачає введення окремого Порядку 
використання негласних методів та засобів у процесі здійснення КРД, який має визначатися на основі цього Закону та нормативно-правових актів СБ України [2, ст. 8]. Згаданий вище Порядок застосування негласних методів КРД досі нормативно не закріплений.

Звертаючи увагу на контррозвідувальні заходи як дії, шляхом проведення яких застосовуються методи КРД, необхідно також зауважити, що в ст. 7 Закону України «Про контррозвідувальну діяльність» закріплені права контррозвідувальних підрозділів СБ України на проведення конкретних заходів. Зокрема, відповідно до п. 6 ч. 2 ст. 7 цього Закону виключно з метою попередження, своєчасного виявлення і припинення розвідувальних, терористичних та інших посягань на державну безпеку України, отримання інформації в інтересах контррозвідки оперативні підрозділи мають право здійснювати оперативно-розшукові заходи, визначені ч. 3 ст. 8 Закону України «Про оперативно-розшукову діяльність» [2, ст. 7; 3, ст. 8]. До зазначених оперативно-розшукових заходів належать спостереження за особою, річчю або місцем, зняття інформації з транспортних телекомунікаційних мереж та електронних інформаційних систем, обстеження публічно недоступних місць, житла чи іншого володіння особи, встановлення місцезнаходження радіоелектронного засобу, арешт, огляд та виїмка кореспонденції тощо. Вони проводяться з використанням оперативних та оперативно-технічних сил і засобів та передбачають тимчасове обмеження конституційних прав та свобод людини. Це свідчить, що застосування СБ України негласних методів КРД може тимчасово обмежувати конституційні права і свободи людини.

У цьому контексті варто зазначити, що Закон України «Про оперативно-розшукову діяльність» щодо організації та порядку проведення зазначених оперативно-розшукових заходів відсилає до положень Кримінального процесуального кодексу України, а саме до Глави 21, в якій визначаються загальні положення про негласні слідчі (розшукові) дії [4]. Зазначений вище порядок проведення, в тому числі і контррозвідувальних заходів, що тимчасово обмежує конституційні права та свободи людини, передбачає погодження своїх дій з органами прокуратури.

Однак доцільно враховувати той факт, що КРД чинним законодавством визначена спеціальним видом діяльності у сфері забезпечення державної безпеки, що за характером виконання завдань у демократичних країнах притаманне спеціальним службам. Адже, згідно з рекомендаціями Парла- ментської Асамблеї Ради Європи № 1713 (2005) «Про демократичний нагляд за положенням у сфері безпеки в країнах - членах», протидія посяганням спецслужб іноземних держав на безпеку країни характерна для служб внутрішньої безпеки та реалізується шляхом здійснення контррозвідувальної діяльності. При цьому в зазначеному документі вказано, що, враховуючи відмінності в завданнях та повноваженнях служб безпеки і розвідувальних служб, з одного боку, та правоохоронних органів з іншого, дуже важливо відобразити ці відмінності в законодавстві [5, п. 13.5].

У зв'язку з викладеним виникає необхідність надати таким державним органам спеціального порядку одержання дозволу на тимчасове обмеження конституційних прав і свобод людини. Необхідність встановлення спеціального порядку одержання дозволу на застосування спецслужбами гласних та негласних методів їхньої діяльності обґрунтовується значною суспільною небезпекою посягань іноземних спецслужб та терористичних організацій на національні інтереси України, а також глибоко законспірованим характером їхньої діяльності.

3 приводу зазначеного цікавим $€$ досвід США як країни, що однією з перших вступила в інформаційну епоху i накопичила вагому практику правового регулювання балансу між гарантіями дотримання прав і свобод людини і завданнями із забезпечення державної безпеки. Так, з одного боку, останніми роками спостерігаємо стійку тенденцію до підвищення прозорості у діяльності спецслужб США. Йдеться, зокрема, про скасування «Акта про патріотизм», який після терактів в США 11 вересня 2001 р. надавав спецслужбам практично необмежені можливості щодо втручання у приватне життя людини, та введення в червні 2015 р. в дію «Акта про свободу США» (USA Freedom Act), який забороняє спецслужбам вести електронне спостереження за громадянами США без спеціального дозволу [6; 7].

Втім вважаємо за необхідне зазначити, що порядок тимчасового обмеження спецслужбами США конституційних прав і свобод людини регулюється також «Актом про негласне спостереження в інтересах зовнішньої розвідки» (так званий закон - FISA). У цьому нормативно-правовому акті закріплена процедура фізичного та електронного спостереження, а також збору зовнішньої розвідувальної інформації, що передається іноземними державами та агентами іноземних держав, які обґрунтовано підозрюються у шпигунстві або тероризмі [8]. Відповідно до положень FISA 
було створено окремий суд (Foreign Intelligence Surveillance Court, FISC), уповноважений видавати судовий ордер на негласне втручання у приватне спілкування за підозрюваними в розвідувальній діяльності на території США за запитом американських спецслужб без жодних погоджень.

Ми не наполягаємо на створенні окремої судової установи, яка б розглядала клопотання контррозвідувальних підрозділів СБ України щодо прийняття рішення з тимчасового обмеження конституційних прав і свобод людини. Однак, на нашу думку, СБ України як державний орган спеціального призначення у сфері забезпечення державної безпеки потребує власного порядку отримання дозволу слідчого судді на застосування спеціальних форм та методів без розкриття інформації третій стороні.

3 огляду на зазначене варто звернути увагу на намагання законодавця виправити зазначену проблему. Так, нині Верховною Радою України розглядається законопроєкт про внесення змін до Закону України «Про контррозвідувальну діяльність», яким пропонується надати право контррозвідувальним підрозділам застосовувати негласні методи КРД, які тимчасово обмежують конституційні права і свободи людини, без погодження з органами прокуратури [9].

Новелою проєкту змін до Закону України «Про контррозвідувальну діяльність» $\epsilon$ також запровадження нової ст. 7-1 «Контррозвідувальне впровадження», на підставі якої контррозвідувальним підрозділам СБ України з метою протидії розвідувально-підривній діяльності проти України, прогнозування, попередження, виявлення та нейтралізації загроз державній безпеці, а також управління ризиками державної безпеки надане право здійснювати контррозвідувальне впровадження до спеціальних служб іноземних держав, закордонних організацій, терористичних організацій та угруповань, міжнародних терористичних організацій та їхніх осередків, організованих злочинних угруповань, незаконних збройних та воєнізованих формувань, інших організацій, установ, структур і утворень, цілі та дії яких спрямовані на створення загроз державній безпеці або підвищення ризиків державної безпеки [9, ст. 7-1]. Нами загалом позитивно сприймаються всі пропозиції з удосконалення організаційно-правового регулювання КРД, однак аналіз запропонованих змін потребує зваженого підходу, недопущення процесуалізації КРД та звуження наявних можливостей застосування СБ України методів цієі діяльності.
Продовжуючи аналіз правового забезпечення застосування СБ України методів КРД, варто звернутись до положень ст. 9 Закону України «Про контррозвідувальну діяльність», в якій чітко зазначається, що відомості про організацію, плани, зміст, форми, методи, засоби, фінансування та матеріально-технічне забезпечення, результати КРД, а також про осіб, які співпрацюють або раніше співпрацювали на конфіденційній основі з органами СБ України, становлять державну таємницю і підлягають захисту в порядку, визначеному Законом України «Про державну таємницю» [2, ст. 9; 10]. Відповідно до зазначених в п. 4.4.1. положень Наказу СБ України від 12.08.2005 р. № 440 «Про затвердження Зводу відомостей, що становлять державну таємницю» відомості за окремими показниками про зміст, форми, методи, організаційні положення, оперативну тактику здійснення органами СБ України КРД, розголошення яких створює загрозу національним інтересам і безпеці, становлять державну таємницю. У п. 4.4.3 цього ж Наказу до відомостей, що становлять державну таємницю, зараховують дані про організацію, завдання, результати контррозвідувальної діяльності, розголошення яких створює загрозу національним інтересам і безпеці [11]. Відповідно до п. 2.6. Переліку відомостей, що становлять службову інформацію у Службі безпеки України, затвердженого Наказом Центрального управління СБ України від 21.08.2012 р. № 400, відомості щодо змісту, форм, методів, організаційних положень, оперативної тактики здійснення СБ України КРД, якщо ці дані не становлять державної таємниці, але їх оприлюднення може завдати шкоди інтересам СБ України, вони належать до службової інформації [12].

Висновки. Таким чином, методи КРД мають власну правову природу. Зокрема, прямі посилання в законодавстві на методи КРД не розкривають їхніх сутнісних та змістовних характеристик, не впливають на формування їх системи, хоча і формулюють окремі з них. При цьому інші норми контррозвідувального законодавства хоча прямо і не вказують на них, але справляють найбільший вплив на їхню правову природу або накладають певні обмеження щодо їх застосування за певних обставин. До зазначених норм можна зарахувати статті, що закріплюють мету та завдання КРД, їі принципи, підстави та форми її проведення, функції і повноваження органів та підрозділів контррозвідки, гарантії дотримання законності під час здійснення КРД тощо. 
Законодавство України $\epsilon$ системним утворенням. Системний аналіз юридичних норм, що становлять правову основу КРД, дав, на наш погляд, змогу, по-перше, відтворити механізм впливу норм права на методи КРД, по-друге, встановити внутрішні та зовнішні юридичні зв'язки між досліджуваною категорією та іншими важливими категоріями КРД, по-третє, зрозуміти залежність між правовою дійсністю та навколишніми соціальними явищами, процесами, на які можуть впливати методи КРД у результаті їх застосування.

\section{Література}

1. Козьяков І.М. Законодавче визначення державної безпеки: проблеми теорії та практики. Підприємництво, господарство і право: теорія держави і права. Київ : НДІ приватного права і підприємництва ім. Ак. Ф.Г. Бурчака НАПрН України. 2019. № 9. С. 160-164.

2. Про контррозвідувальну діяльність : Закон України від 03.04.2003 р. Відомості Верховної Ради України. 2003. № 12. Ст. 89.

3. Про оперативно-розшукову діяльність : Закон України від 02.06.1992 р. Відомості Верховної Ради України. 1992. № 22. Ст. 303.

4. Кримінальний процесуальний кодекс України від 13.04.2012 р. за № 4651-VI. Голос України. 19.05.2012. Ст. 90-91.

5. Про виконання обов'язків та зобов'язань Україною : Резолюція 1466 (2005) Парламентської Асамблеї Ради Європи. URL: https://zakon.rada.gov.ua/ $\mathrm{rada} / \mathrm{show} / \mathrm{ru} / 994$ 611.

6. The USA PATRIOT Act: Preserving Life and Liberty (Uniting and Strengthening America by
Providing Appropriate Tools Required to Intercept and Obstruct Terrorism). URL: https://web.archive. org/web/20100102035036/http://www.justice.gov/ archive/ll/highlights.htm.

7. H.R.2048 - USA FREEDOM Act of 2015. URL: https: / /www.congress.gov/bill/114th-congress/housebill/2048?q=\%7B"search"\%3A\%5B"USA+Freedom+Act"\%5 D\%7D.

8. Foreign Intelligence Surveillance Act. URL: https: / / legcounsel.house.gov/Comps/Foreign $\% 20$ Intelligence\%20Surveillance\%20Act\%200f\%201978.pdf.

9. Про Службу безпеки України» щодо удосконалення організаційно-правових засад діяльності Служби безпеки України : Проєкт Закону № 3196 від 10.03.2020 р. про внесення змін до Закону України. URL: https://w1.c1.rada.gov.ua/pls/zweb2/ webproc4_1?pf3511=68347.

10. Про державну таємницю : Закон України від 21.01.1994 p. URL: http://zakon2.rada.gov.ua/laws/ show/964-15.

11. Про затвердження Зводу відомостей, що становлять державну таємницю : Наказ Голови СБ України від 12.08.2005 р. № 440 (зареєстровано в міністерстві юстиції України 17 серпня 2005 р. за № 902/11182). Офіційний вісник України. 2005. № 34. СТ. 2089.

12. Про затвердження Переліку відомостей, що становлять службову інформацію у Службі безпеки України : Наказ ЦУ СБ України від 21.08.2012 р. № 400. URL: https://ssu.gov.ua/ua/pages/121

Пелюх О. С., кандидат юридичних наук, докторант відділу аспірантури і докторантури Національної академії Служби безпеки України 